\title{
Role of receptors for epidermal growth factor and insulin-like growth factors I and II in the differentiation of rat mammary glands from lactogenesis I to lactogenesis II
}

\author{
L. E. Bussmann, I. M. Bussmann and E. H. Charreau \\ Instituto de Biologia y Medicina Experimental-CONICET, Vuelta de Obligado 2490, Buenos Aires (1428), \\ Argentina
}

In addition to ovarian steroids and lactogenic hormones from the placenta and pituitary, growth factors control the growth and differentiation of mammary glands. Lactogenesis II at the end of pregnancy is under the control of progesterone. Ovariectomy results in a significant decrease in the number of receptors for epidermal growth factor (EGF) and insulin-like growth factor I (IGF-I) and an increase in IGF-II binding sites in mammary gland acini of rats, without affecting the affinity for their respective ligand. Although concentrations of EGF, IGF-I and IGF-II receptors are regulated by oestradiol and progesterone, replacement treatment with ovarian steroids after ovariectomy showed that receptor concentrations do not mediate the restraint on lactogenesis. Progesterone treatment, which inhibits the onset of lactogenesis II, did not restore EGF receptor concentrations to control values, and the presence of oestradiol was required to reverse the effect of ovariectomy. Oestradiol, which potentiates the effect of ovariectomy on milk synthesis, increases IGF-I receptor concentrations. IGF-II receptor concentrations, after the different steroid treatments, were consistent with the steroid effect on milk synthesis. The changes observed in the concentrations of these growth factor receptors at the onset of mammary gland secretion are not considered to affect the progesterone block to lactogenesis II, but rather are a consequence of the shift of the hormonal and, hence, physiological status of the gland.

\section{Introduction}

Lactogenesis or the onset of milk synthesis is a two stage process in rats that occurs during late pregnancy (Fleet et al., 1975). Lactogenesis I is characterized by the appearance of biosynthetic activity of the mammary gland in the last third of pregnancy and milk synthesis is under the control of progesterone. Lactogenesis II takes place a few hours before, or at, parturition, when progesterone serum values fall and the steroid block to milk synthesis is removed. Both stages of lactogenesis are controlled primarily in the rat by ovarian and adrenal steroids and lactogenic hormones from the pituitary and placenta (Topper and Freeman, 1980). However, the unequivocal role of a particular hormone in mammary gland differentiation is difficult to ascertain, due to the interactions between the hormones. Apart from its own particular action, each hormone modulates the secretion or the effects of the others.

A number of studies have indicated that some growth factors are involved in the differentiation of the mammary gland. Among them, insulin-like growth factors (IGFs) and epidermal growth factor (EGF) play a major role in this process (Dembinski and Shiu, 1987).
Serum concentrations of EGF increase during pregnancy in mice (Dembinski and Shiu, 1987), and studies in vitro have shown the mitogenic effects of EGF on the mammary epithelial cells of humans (Papadimitriou et al., 1977) and mice (Turkington, 1969). The effect of EGF on milk protein synthesis in vitro is controversial. Initially, an inhibitory effect in a dose-dependent manner was reported (Taketani and Oka, 1983). However, when EGF was given in the presence of a physiological insulin concentration, there was no effect on casein synthesis (Sankaran and Topper, 1987).

The biological actions of EGF are mediated by a specific receptor which has protein tyrosine kinase activity and is located on the cell membrane (Carpenter and Cohen, 1979). EGF receptors are expressed in the mammary glands of mice and their concentration changes according to the different reproductive stages, reaching a maximum in mid-pregnancy and declining thereafter throughout parturition and lactation (Edery et al., 1985).

The mitogenic effect of IGF-I was observed in a human breast cancer cell line (Myal et al., 1984) and in mammary cells from mice (Imagawa et al., 1986). IGF-I is believed to mediate the galactopoietic action of growth hormone in cows (Davis et al, 1987), although in a recent report in rats with suppressed lactation, treatment with IGF-I analogues failed to mimic the action of growth hormone (Flint et al., 1994). 
The effect of IGFs is initiated by the specific binding to their cell-surface receptors. The type I receptor has a high affinity for IGF-I and a lower affinity for IGF-II and insulin (Kasuga et al., 1981). The type II receptor which has a higher affinity for IGF-II than for IGF-I and does not bind insulin was recently identified as the mannose 6-phosphate receptor (MacDonald et al., 1988).

The trigger for lactogenesis at the end of pregnancy is the fall in circulating concentrations of progesterone, which allows the differentiated mammary gland to begin milk synthesis (Kuhn, 1969). The inhibitory effect of progesterone does not correlate with receptor concentrations (Shyamala and McBlain, 1979) which could indicate that the effect of progesterone on the mammary acini is indirect and acts through the modulation of the production of growth factors or their receptors. In the present study the effect of ovariectomy and steroid replacement treatment on the concentration of membrane receptors for EGF and IGFs was investigated.

\section{Materials and Methods}

All chemicals were reagent grade and obtained from Sigma Chemical Co. (St Louis, MO) unless otherwise indicated. mEGF receptor-grade and rabbit anti-mEGF antibody were obtained from Collaborative Research Inc. (Bedford, MA). Transforming growth factor- $\alpha$ (TGF $\alpha$ ) AffiPure sheep antibody was from Triton Biosciences Inc. (Alameda, CA). rhIGF-I and rhIGF-II were kindly donated by J. Merrywheather from Chiron Corporation (Emerville, CA). Na ${ }^{125} \mathrm{I}$, carrier-free was purchased from New England Nuclear Corp. (Boston, MA). Reagents for polyacrylamide gel electrophoresis and anion exchange resin AG $1 X_{2}$ were purchased from Bio-Rad (Richmond, CA). Heparin-Ultrogel A4R was from IBF Biotechnics (Villeneuve-la-Garenne). Disuccinimidyl suberate (DSS) was obtained from Pierce Chemical Co. (Rockford, IL) and centricon 30 was purchased from Amicon (Beverly, MA).

\section{Animals and general methodology}

White, nulliparous rats, about 3-months-old (180-200 g), were caged with a male rat during the night after pro-oestrus. The next morning was taken as day 0 of pregnancy if spermatozoa were found in the vaginal smear. In our colony, rats usually deliver on day 22 . The rats were given food and water ad libitum and kept in a constant-temperature room $\left(22 \pm 2^{\circ} \mathrm{C}\right)$ with a controlled light cycle (lights on from 07:00 to 19:00 h).

Lactogenesis II was induced by bilateral ovariectomy performed between 09:00 and 11:00 h on day 18 of pregnancy through dorsolateral incisions under light ether anaesthesia; in control animals (sham-operated) only the incision was performed. Steroid replacement treatment was performed by s.c. injection. Progesterone (10 mg in $0.1 \mathrm{ml}$ oil) was given after surgery and again $12 \mathrm{~h}$ later. Oestradiol (oestradiol benzoate $I \mu \mathrm{g}$ in $0.1 \mathrm{ml}$ oil) was injected $12 \mathrm{~h}$ after ovariectomy. The rats were killed by decapitation $24 \mathrm{~h}$ later and the inguinal mammary glands removed immediately and placed in ice-cold PBS. The presence of milk was assessed by the oxytocin test, as described by Bussmann and Deis (1979). Lactating mammary glands were obtained from rats at day 7 of lactation.

\section{Preparation of mammary acini and membrane isolation}

The use of membranes isolated from mammary acini preparations decrease the contribution of extracellular components in the receptor determination assay due to the low proportion of acini present in the gland at day 19 of pregnancy. For this reason, acini were isolated according to Threadgold et al. (1982). Briefly, mammary tissue was minced and enzymatically dissociated at $37^{\circ} \mathrm{C}$ by treatment with $0.1 \%$ $(\mathrm{w} / \mathrm{v})$ collagenase in medium DMEM-F12 with $15 \mathrm{mmol}$ Hepes $1^{-1}, \mathrm{pH} 7.4$, in the presence of BSA radioimmunoassay grade $(2 \% \mathrm{w} / \mathrm{v})$ and Ficoll-400 $(5 \% \mathrm{w} / \mathrm{v})$ in a plastic tube. The tube was shaken at 200 strokes $\mathrm{min}^{-1}$ for $60 \mathrm{~min}$. The digested tissue was filtered through Nitex $150 \mu \mathrm{m}$ (Tobler, Ernst and Traber, Inc., New York) and the acini sedimented at $300 \mathrm{~g}$ for $90 \mathrm{~s}$ over a cushion of Ficoll- $400(35 \% \mathrm{w} / \mathrm{v})$. The acini were resuspended in the same medium plus $2 \%(\mathrm{w} / \mathrm{v})$ Ficoll and $1 \%$ $(\mathrm{w} / \mathrm{v}) \mathrm{BSA}$, and sedimented as before. The entire washing procedure was repeated and finally the acini collected from the Ficoll cushion and resuspended in nine volumes $(\mathrm{w} / \mathrm{v})$ of hypotonic buffer ( $10 \mathrm{mmol}$ Tris $1^{-1}, \mathrm{pH} 7.4$ with $1 \mathrm{mmol}$ EDTA ${ }^{-1}$ ). Similar concentrations of DNA were present in the suspensions from control and ovariectomized rats (control 2.26-2.54 mg versus ovariectomized 2.1-2.58 mg DNA per $100 \mathrm{mg}$ of acini). The acini were left for $10 \mathrm{~min}$ on ice before homogenization by Ultra Turrax (IKA-Labortechnik, Germany) with three bursts of $15 \mathrm{~s}$. The homogenate was diluted with half its volume of sucrose buffer $\left(0.75 \mathrm{~mol}\right.$ sucrose $\mathrm{l}^{-1}, 1 \mathrm{mmol}$ EDTA $\mathrm{l}^{-1}$ in $10 \mathrm{mmol}$ Tris $\left.\mathrm{l}^{-1}, \mathrm{pH} 7.4\right)$ and centrifuged at $10000 \mathrm{~g}$ for $10 \mathrm{~min}$. The supernatant was made up with $10 \mathrm{mmol} \mathrm{MgCl} \mathrm{l}^{-1}$ and centrifuged at $40000 \mathrm{~g}$ for $20 \mathrm{~min}$, after which the pellet was resuspended in buffer $(10 \mathrm{mmol}$ Tris $\mathrm{I}^{-1}, 2 \mathrm{mmol} \mathrm{MgCl} \mathrm{L}^{-1}, \mathrm{pH} 7.4$ in a ratio (w:v) of 1 original cell pellet after collagenization to 14 buffer) and used as the membrane preparation. Protein concentrations, between or within groups, were not different.

Homogenization and all the incubations that followed were carried out in the presence of $0.5 \mathrm{mmol}$ PMSF $\mathrm{I}^{-1}$ (phenylmethylsulphonyl fluoride), $0.025 \mathrm{mmol} \mathrm{ZPCK} \mathrm{l}^{-1}$ (N-CBZ-Lphenylalanine chloromethyl ketone), $0.025 \mathrm{mmol}$ TLCK $1^{-1}$ ( $N^{\prime}-p$-tosyl-lysine chloromethyl ketone), $0.025 \mathrm{mmol}$ TPCK $\mathrm{I}^{-1}$ (L-1-tosylamide-2-phenyl-ethylchloromethyl ketone) as proteases inhibitors.

Desaturation of the membrane receptors was performed by resuspending the pellet in $50 \mathrm{mmol}$ glycine $\mathrm{l}^{-1}, 100 \mathrm{mmol}$ $\mathrm{NaCl} 1^{-1}, \mathrm{pH} 3.0$ and incubating for $10 \mathrm{~min}$ at room temperature. Then, $1 / 20$ volume 1 mol Tris $1^{-1}, \mathrm{pH} 8.0$, was added and the suspension centrifuged at $40000 \mathrm{~g}$ for $20 \mathrm{~min}$. The pellet was suspended in $50 \mathrm{mmol}$ Tris $\mathrm{I}^{-1}, 2 \mathrm{mmol} \mathrm{MgCl}_{2} \mathrm{l}^{-1}$, pH 7.4 and the supernatant set aside for the determination of endogenous EGF by radioimmunoassay (Molinolo et al., 1987) or radioreceptor assay (Elizalde et al., 1990a). The sensitivities of the assays were $10 \mathrm{pg}$ and $150 \mathrm{pg}$, respectively.

\section{Iodination}

Labelling of IGF-I, IGF-II and EGF with ${ }^{125}$ I was performed by the chloramine- $\mathrm{T}$ method, followed by purification by Sephadex G-50 chromatography as described by Elizalde $e t$ al. (1990b). Aliquots were kept frozen at $-70^{\circ} \mathrm{C}$ and before use 
they were taken up in $0.2 \mathrm{~mol}$ acetic acid $l^{-1}$ and treated with AG-1-X2 anion exchange resin. The resultant tracers were characterized as having a specific activity of $100-120 \mu \mathrm{Ci}$ $\mu \mathrm{g}^{-1}$ and a maximum binding capacity of $60-70 \%$ for EGF and $30-40 \%$ for IGF-I and IGF-II, as determined by binding to excess placental membrane receptors.

\section{Receptor assay}

EGF, IGF-I and -II receptors were assessed as described by Molinolo et al. (1987) and Elizalde et al. (1990b), with minor modifications. Duplicate $100 \mu \mathrm{l}$ samples of membrane preparation $(25-50 \mu \mathrm{g}$ protein) were incubated with different concentrations of the tracer ranging from $1 \times 10^{-11}$ to $1 \times 10^{-9} \mathrm{~mol} \mathrm{I}^{-1}$, in a final volume of $200 \mu \mathrm{l}$ TBSA buffer (50 mmol Tris $1^{-1}, 2$ mmol $\mathrm{MgCl}_{2} \mathrm{l}^{-1}, 1 \%$ (w/v) BSA radioimmunoassay grade) in plastic tubes overnight at $4^{\circ} \mathrm{C}$. Incubation was stopped by placing the samples on ice and adding $2 \mathrm{ml}$ TBSC buffer $\left(50 \mathrm{mmol}\right.$ Tris $\mathrm{l}^{-1}, 10 \mathrm{mmol} \mathrm{MgCl}_{2} \mathrm{l}^{-1}$, $0.1 \%(\mathrm{w} / \mathrm{v}) \mathrm{BSA}, 0.1 \%(\mathrm{w} / \mathrm{v})$ celite, $\mathrm{pH} 7.0)$.

Membrane-bound growth factor was separated by centrifugation at $6000 \mathrm{~g}$ for $30 \mathrm{~min}$, the supernatant discarded and the pellet counted in a LKB gamma spectrometer (LKB Instruments, Wallack, Sweden). Non-specific binding was assessed in each experiment, and for each concentration of the respective tracer, by incubating samples in duplicate with an excess $\left(3 \times 10^{-7} \mathrm{~mol} \mathrm{l}^{-1}\right)$ of unlabelled growth factor. The amount of growth factor bound in this condition was usually less than $2 \%$ of the total radioactivity present. The non-specific binding was subtracted from total binding to obtain specific binding. Scatchard plots (Scatchard, 1949) were used to determine equilibrium constants $\left(K_{\mathrm{d}}\right)$ and the number of receptors, using the program LIGAND (Munson and Rodbard, 1980). For comparison between groups treated with ovarian steroids and their respective controls, receptor concentrations were determined by incubating the membrane preparations with a single saturating concentration of the tracer $\left(1 \times 10^{-9} \mathrm{~mol} \mathrm{l}^{-\mathrm{I}}\right)$ in the presence or absence of an excess $\left(3 \times 10^{-6} \mathrm{~mol} \mathrm{l}^{-1}\right)$ of unlabelled growth factor. Under these conditions non-specific binding was high $(30-40 \%$ of the total binding) but values for receptor concentrations were in agreement with those obtained by Scatchard analysis. Binding is expressed per $\mathrm{mg}$ of membrane protein, instead of DNA content or number of cells, to avoid variability due to differences in the number of cells disrupted in the homogenization process.

The concentration of growth factors in the mammary glands was measured in the alcohol-acid extract obtained as described by Roberts et al. (1980) by radioreceptor assay using membranes from human placenta stripped of endogenous growth factors by treatment with $50 \mathrm{mmol}$ glycine $\mathrm{l}^{-1}, 100 \mathrm{mmol}$ $\mathrm{NaCl} \mathrm{l}^{-1}, \mathrm{pH} 3.0$. The alcohol-acid extract was dialysed against $0.17 \mathrm{~mol}$ acetic acid $\mathrm{l}^{-1}$ and then centrifuged at $5000 \mathrm{~g}$ in a Centricon 30 until all the sample passed through. The retentates were rinsed once with $0.2 \mathrm{ml} 0.17 \mathrm{~mol}$ acetic acid $\mathrm{l}^{-1}$, and after centrifugation the residues were taken up in $1 \mathrm{ml}$ $0.17 \mathrm{~mol}$ acetic acid $\mathrm{l}^{-1}$. Aliquots of the alcohol-acid extracts, the suspended retentates $(>30 \mathrm{kDa})$ and the filtrates $(<30 \mathrm{kDa})$ were lyophilised and suspended in TBSA buffer. The incubation procedure was as for receptor determination using 40000 c.p.m. of tracer and various amounts of the alcohol-acid extract. The same growth factors used for iodination were used for the standard curve. The sensitivity of the assay for EGF activity was $150 \mathrm{pg}$ per tube. The mean intra-assay coefficient of variation was $9 \%$.

Affinity labelling was performed by incubating $50 \mu \mathrm{g}$ of membrane protein with 500000 c.p.m. of ${ }^{125}$ I-labelled IGF-I or IGF-II overnight at $4^{\circ} \mathrm{C}$ in a final volume of $0.2 \mathrm{ml}$ TBSA buffer. The reaction was stopped by adding $1 \mathrm{ml}$ ice-cold PBS and further centrifugation at $10000 \mathrm{~g}$ for $10 \mathrm{~min}$. The pellet was resuspended in $0.195 \mathrm{ml}$ PBS and cross-linking was performed by addition of $5 \mu \mathrm{l} 4 \mathrm{mmol}$ disuccinimidyl suberate (DSS) $\mathrm{l}^{-1}$ in dimethyl sulfoxide and ice-bath incubation. After $15 \mathrm{~min}$,

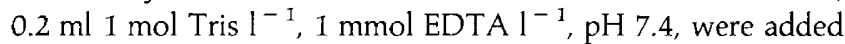
and the incubation allowed to proceed for another $10 \mathrm{~min}$, followed by the addition of $1 \mathrm{ml}$ cold distilled water and centrifugation at $10000 \mathrm{~g}$ for $10 \mathrm{~min}$. Pellets were then solubilized by boiling in sample buffer $\left(62.5 \mathrm{mmol}\right.$ Tris $\mathrm{l}^{-1}$, $15 \mathrm{mmol}$ dithiothreitol $\mathrm{l}^{-1}, 1 \%(\mathrm{w} / \mathrm{v})$ SDS, $15 \%(\mathrm{v} / \mathrm{v})$ glycerol, $\mathrm{pH}$ 6.8). The proteins were separated on a $4-10 \%$ polyacrylamide gel gradient SDS-PAGE system. The gels were fixed in $40 \%$ methanol-10\% acetic acid (v/v) and dried. Kodak XAR-5 film (Eastman Kodak, Rochester, USA) was exposed at $-70^{\circ} \mathrm{C}$ with intensifying screen (DuPont Cronex, DuPont, Wilmington, DE) for 4-7 days. The relative intensity of each band was determined with a gel-scan densitometer (Ultroscan XL laser densitometer, LKB Broma, Sweden).

Western blot analysis of the alcohol-acid extract was performed as described by Stein et al. (1995) after protein separation on a 10-20\% polyacrylamide gel gradient SDSPAGE. The sensitivity of the assay for TGF $\alpha$ was $5 \mathrm{ng}$.

Protein determinations were performed after digestion of a sample of membrane preparation with $1 \mathrm{~mol} \mathrm{NaOH} \mathrm{l}{ }^{-1}$ according to the method of Lowry et al. (1951) using BSA as standard. DNA was determined in the sonicated samples resuspended in buffer TNE (10 $\mathrm{mmol}_{\text {Tris }} \mathrm{l}^{-1}, 100 \mathrm{mmol} \mathrm{NaCl}$ $\mathrm{l}^{-1}, 1 \mathrm{mmol}$ EDTA $\left.1^{-1}, \mathrm{pH} 7.4\right)$. After the addition of the fluorochrome Hoechst 33258, the fluorescence was read in a TKO 100 minifluorometer (Hoefer Scientific Instruments, CA, USA). Salmon testes DNA was used as standard.

\section{Statistical analyses}

Results are given as means $\pm \mathrm{SEM}$, with the number of observations in parentheses. Analysis of the data was performed by ANOVA, and differences between groups were assessed by Scheffé's multiple contrasts. The Mann-Whitney test was used for the Scatchard values owing to the number of observations. $P<0.05$ was considered to be statistically significant.

\section{Results}

\section{EGF receptors}

Scatchard analysis of the binding of ${ }^{125}$ I-labelled EGF to membrane preparations of mammary acini from intact or ovariectomized rats at day 19 of pregnancy showed a single class of high-affinity binding sites with similar $K_{d}$ values 


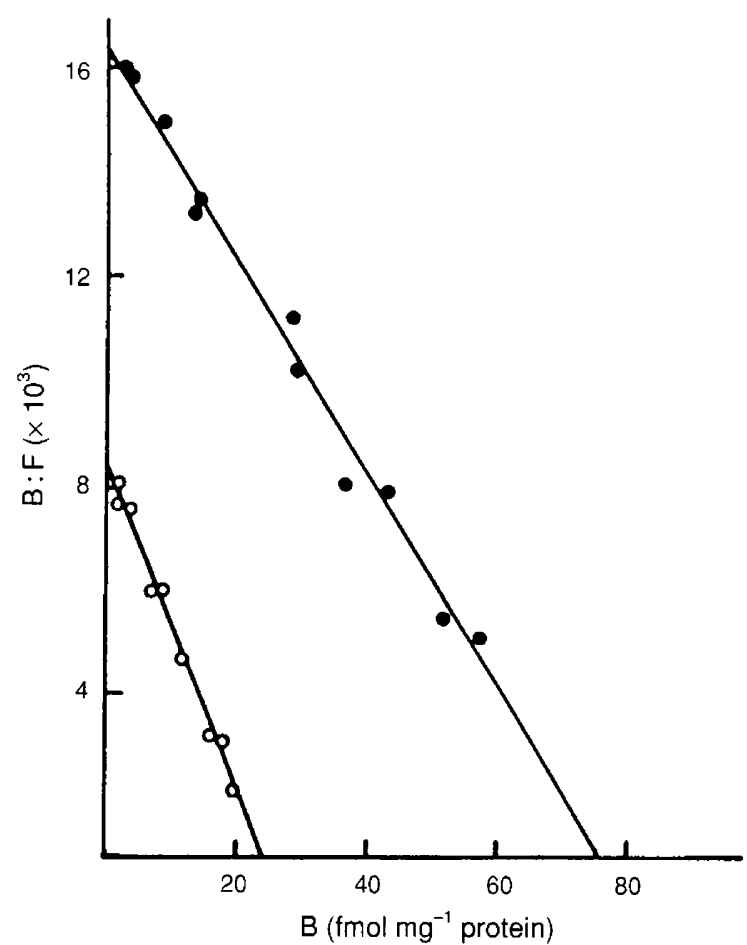

Fig. 1. Scatchard plot of the binding of ${ }^{125} \mathrm{I}$-labelled epidermal growth factor (EGF) to mammary acini membranes from $(O)$ control and $(O)$ ovariectomized rats at day 19 of pregnancy. Samples of membranes (25-50 $\mu$ g protein) were incubated with increasing amounts of ${ }^{125} \mathrm{I}$ labelled EGF $\left(4.4 \times 10^{-11}-1.44 \times 10^{-9} \mathrm{~mol} \mathrm{l}^{-1}\right)$ in the presence or the absence of $3 \times 10^{-7} \mathrm{~mol} \mathrm{I}^{-1}$ unlabelled EGF, in order to assess non-specific binding. Values are the means of four experiments. $K_{\mathrm{d}}=1.1 \mathrm{nmol} \mathrm{l}^{-1}$ for control rats and 0.71 for ovariectomized rats.

$\left(1.1 \pm 0.05(n=4)\right.$ and $0.71 \pm 0.07(n=5) \mathrm{nmol} \mathrm{l}^{-1}$, respectively) (Fig. 1). Receptor concentration was lower in the differentiated gland than in the controls (control $71.2 \pm 17$ $(n=4) \mathrm{fmol} \mathrm{mg}^{-1}$ protein; ovariectomized $24.9 \pm 7.4(n=5)$ fmol $\mathrm{mg}^{-1}$ protein, $P<0.05$ ) and similar to that found in those glands in which lactation was already established (25.7 \pm 7 $(n=4) \mathrm{fmol}^{-1}{ }^{-1}$ protein).

In spite of the presence of EGF in milk, the decrease in receptor content is not due to the occupancy of the receptor sites by endogenous ligands, since acid treatment of membranes did not change the observed results. Moreover, EGF could not be measured in the lyophilised acid supernatants either by radioimmunoassay or radioreceptor assays. These results do not exclude down regulation of receptors or ligand processing.

In the ovariectomized rats, progesterone treatment, which effectively blocks lactogenesis II, did not prevent the decrease in EGF receptors. Oestrogen, when given alone, further diminished EGF binding, but the combination of oestradiol and progesterone restored EGF receptor concentrations to values present in intact rats at day 19 of pregnancy (Fig. 2).

To find out whether the down-regulation of the EGF receptor, seen after oestrogen treatment, was caused by its own ligand, the acid-alcohol extract of the mammary glands was examined for the presence of EGF. The growth factor was not detected in any of the groups by radioimmunoassay, using a

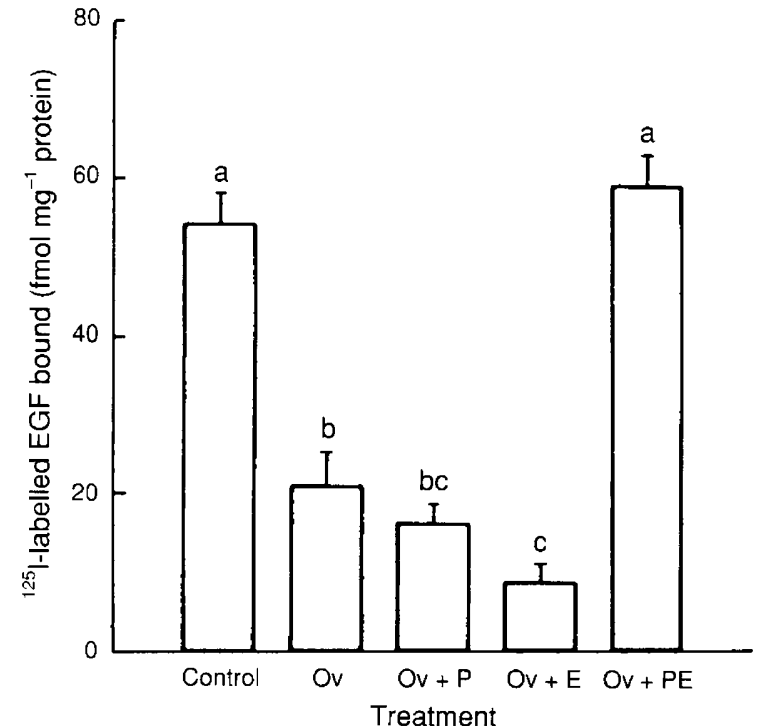

Fig. 2. Effect of steroid replacement to ovariectomized rats on the concentration of the epidermal growth factor (EGF) receptor. Membranes from mammary gland acini of control, ovariectomized $(\mathrm{Ov})$, and ovariectomized treated with progesterone $(\mathrm{Ov}+\mathrm{P})$, oestradiol $(\mathrm{Ov}+\mathrm{E})$ or progesterone plus oestradiol $(\mathrm{Ov}+\mathrm{PE})$ were incubated

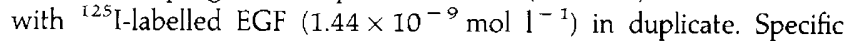
membrane-bound labelled EGF is expressed as fmol $\mathrm{mg}^{-1}$ protein. Values are means $\pm \mathrm{SEM} ; n=5$ rats per group. Bars with the same letter(s) are not significantly different at $P<0.05$.

rabbit polyclonal anti-mEGF; however when a radioreceptor assay was used, all the extracts showed EGF-like activity. Those extracts from the mammary glands of oestradiol-treated rats presented higher values of EGF-like activity and were significantly different from the other groups (oestradiol-treated $43.2 \pm 7.2(n=3) \mathrm{ng} \mathrm{g}^{-1}$ of mammary gland versus intact $4.0 \pm 1.7(n=3)$ and ovariectomized $\left.4.55 \pm 1.8(n=3) \mathrm{ng} \mathrm{g}^{-1}\right)$.

\section{IGF-I binding}

The binding of ${ }^{125}$ I-labelled IGF-I to membranes from mammary cells from control or ovariectomized rats at day 19 of pregnancy, when analysed according to Scatchard, showed only one class of high-affinity, low-capacity binding sites with similar $K_{\mathrm{d}}$ values to those seen at the onset of lactation $\left(0.085 \pm 0.01(n=4)\right.$ and $0.12 \pm 0.05(n=4) \mathrm{nmol} \mathrm{l}^{-1}$, respectively). However, a fall in receptor concentration occurred, together with the appearance of mammary gland secretions, after ovariectomy $\left(592 \pm 35(n=4) \mathrm{fmol} \mathrm{mg}^{-1}\right.$ protein in intact rats versus $274 \pm 43(n=4) \mathrm{fmol} \mathrm{mg}^{-1}$ protein in the ovariectomized rats; $P<0.05$ ).

The specificity of ${ }^{125}$ I-labelled IGF-I binding to membranes from intact or ovariectomized rats was determined by incubating the tracer in the presence of $0-2000 \mathrm{ng} \mathrm{ml}^{-1}$ IGF-I, IGF-II and insulin. A $50 \%$ displacement in the binding was observed

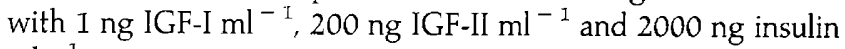
$\mathrm{ml}^{-1}$

Covalent cross-linking of ${ }^{125}$ I-labelled IGF-I to the receptor was also performed (Fig. 3). Two bands with an apparent molecular mass of 134 and $257 \mathrm{kDa}$ (mean of three 

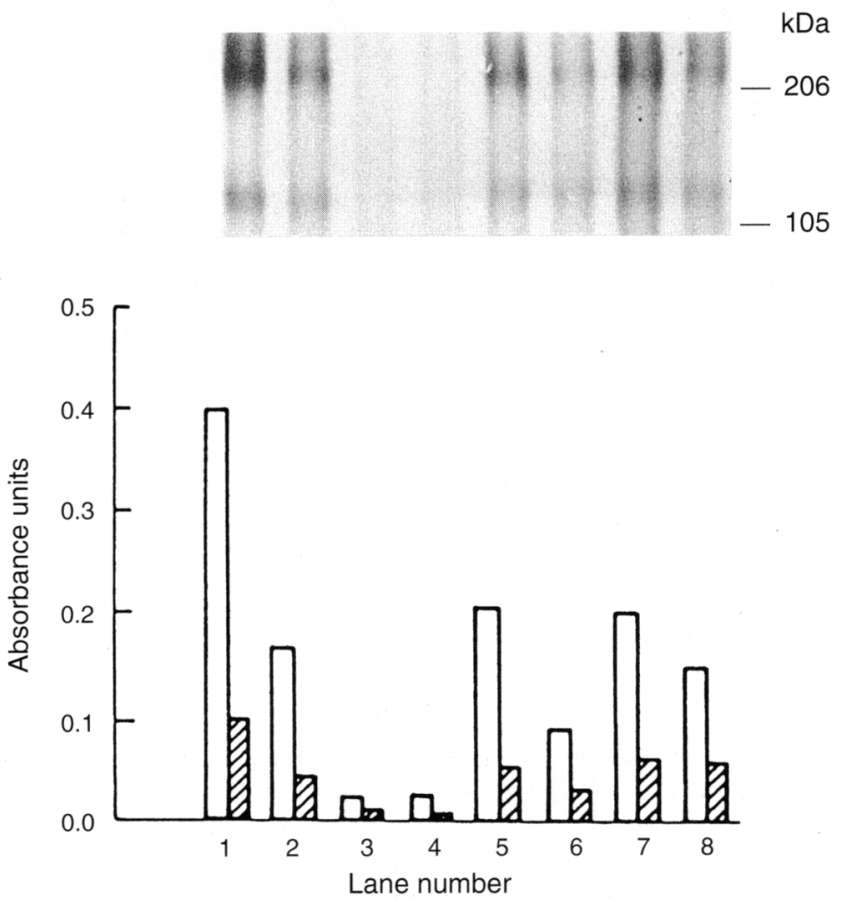

Fig. 3. Representative fluorography of cross-linked ${ }^{125}$ I-labelled insulin-like growth factor I (IGF-I) bound to mammary acini membranes from control (lanes 1, 3, 5 and 7) or ovariectomized rats (lanes $2,4,6$ and 8 ) preincubated in the absence (lanes 1 and 2) or in the presence of $3 \times 10^{-7}$ mol IGF-I $1^{-1}$ (lanes 3 and 4), IGF-II (lanes 5 and 6) and insulin (lanes 7 and 8). Positions of the molecular mass markers are indicated on the right. Bars under the lanes represent the absorbance of the cross-linked receptor quantified by densitometry. (口) $257 \mathrm{kDa}$; band ( $\square$ ) $134 \mathrm{kDa}$ band.

experiments) were detected. Laser scanning densitometry of the autoradiography confirmed the results obtained by equilibrium-binding analysis. Ovariectomy caused a decrease in IGF-I binding of both bands and the specificity of the binding was confirmed by competition with IGF-II and insulin. The ratio between the absorbance of the lower and higher molecular mass bands (0.26) remained constant in all the cases and may indicate that the high molecular mass moiety is a dimer of the $\alpha$-subunit of the IGF-I receptor.

Replacement treatment of ovariectomized rats with ovarian steroids (Fig. 4) revealed that, at least in part, the decrease in ${ }^{125}$ I-labelled IGF-I binding was not due to the IGF present in milk. Oestradiol, which increases milk secretion, also increased receptor concentrations to values not different from those of the control group, and progesterone which abolishes lactogenesis induced by ovariectomy, did not prevent the decrease in IGF-I binding.

\section{IGF-II binding}

IGF-II binds to the membranes from mammary cells with high affinity and with similar $K_{\mathrm{d}}$ values for both intact and ovariectomized rats at day 19 of pregnancy $(0.11 \pm 0.04(n=3)$ and $0.1 \pm 0.01(n=3) \mathrm{nmol} \mathrm{l}^{-\mathrm{I}}$, respectively). The number of receptors slightly increased with the initiation of lactation (intact: $547 \pm 29(n=3) \mathrm{fmol} \mathrm{mg}^{-1}$ protein; ovariectomized:

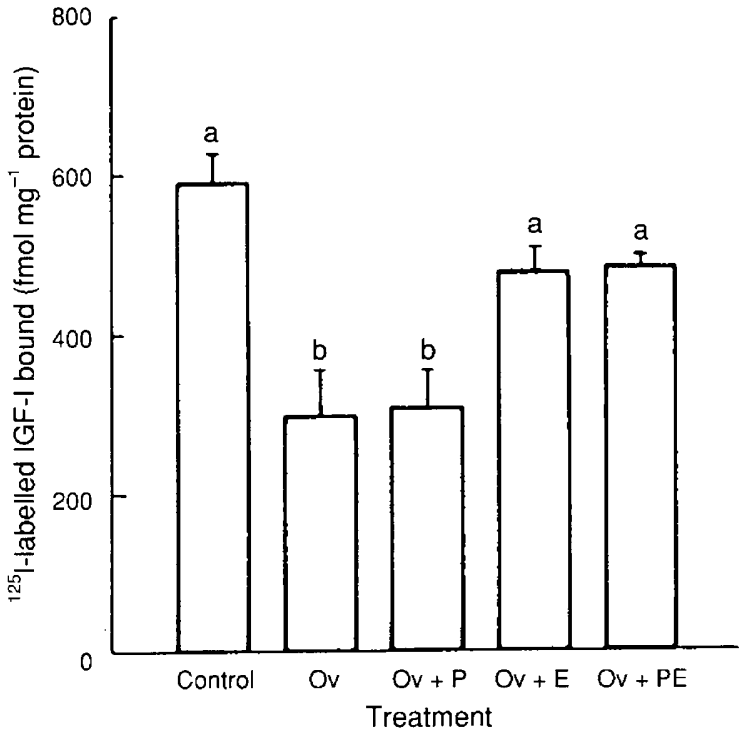

Fig. 4. Effect of steroid replacement to ovariectomized rats on the concentration of the insulin-like growth factor I (IGF-I) receptor. Membranes from mammary gland acini of control, ovariectomized $(\mathrm{Ov})$, and ovariectomized treated with progesterone $(\mathrm{Ov}+\mathrm{P})$, oestradiol $(\mathrm{Ov}+\mathrm{E})$ or progesterone plus oestradiol $(\mathrm{Ov}+\mathrm{PE})$ were incubated as described in Materials and Methods. Values are means \pm SEM; $n=5$ rats per group. Bars with the same letter(s) are not significantly different at $P<0.05$.

$666 \pm 9(n=3)$ fmol $\mathrm{mg}^{-1}$ protein). Affinity labelling of membranes with ${ }^{125}$ I-labelled IGF-II followed by SDS-PAGE (Fig. 5) showed a band with an apparent molecular mass of $235 \mathrm{kDa}$ (mean of three experiments). Laser scanning densitometry revealed an increase in binding to a receptor type II simultaneously with gland differentiation caused by ovariectomy. Binding specificity was confirmed by competition with $3 \times 10^{-7} \mathrm{~mol} 1^{-1}$ of non-radioactive IGF-I and insulin.

The identity of the receptor as a type $11 /$ mannose 6-phosphate receptor was investigated by incubation of membranes from control animals and ${ }^{125}$ I-labelled IGF-II with increasing concentrations of mannose 6-phosphate $\left(0.5 \mu \mathrm{mol}-10 \mathrm{mmol} \mathrm{l}^{-1}\right)$. At the highest concentration of the sugar, binding increased by about $70 \%$. Affinity labelling of membranes incubated with ${ }^{125}$ I-labelled IGF-II in the presence of $5 \mathrm{mmol}$ mannose 6-phosphate $\mathrm{l}^{-1}$, followed by SDS-PAGE (Fig. 6) showed an enhancement of the $235 \mathrm{kDa}$ band. However, when ${ }^{125}$ I-labelled IGF-I was used the $257 \mathrm{kDa}$ band did not increase in the presence of the sugar (data not shown).

Treatment with ovarian steroids affected IGF-II binding as well as lactogenesis. Progesterone decreased the binding in ovariectomized rats to control values, while oestradiol increased the binding to values significantly different from the control rats (Fig. 7).

\section{Discussion}

The results presented here confirm and extend previous studies on changes to EGF and IGF receptors in mammary glands at different physiological stages (Edery et al., 1985; Collier et al., 

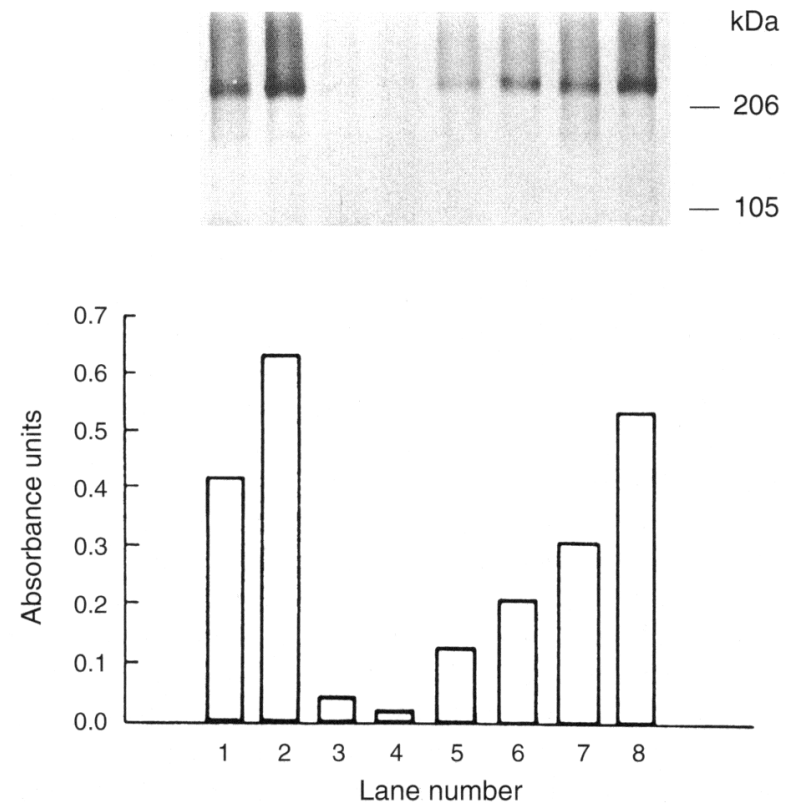

Fig. 5. Representative fluorography of cross-linked ${ }^{125}$ I-labelled insulin-like growth factor II (IGF-II) bound to mammary acini membranes from control (lanes 1, 3, 5 and 7) or ovariectomized rats (lanes 2, 4,6 and 8) preincubated in the absence (lanes $I$ and 2) or in the presence of $3 \times 10^{-7} \mathrm{~mol} \mathrm{l}^{-1}$ of IGF-II (lanes 3 and 4), IGF-I (lanes 5 and 6) and insulin (lanes 7 and 8). Positions of the molecular mass markers are indicated on the right. Bars under the lanes represent the absorbance of the cross-linked receptor quantified by densitometry.

1989). The trigger for lactogenesis II at the end of pregnancy is the fall in circulating concentrations of progesterone. Ovariectomy, which induces lactogenesis (Liu and Davis, 1967), provides an appropriate model of the mammary gland with the same degree of development as that in the intact animal, but that synthesises milk. The biosynthetic activity of the mammary gland induced by ovariectomy is not of the same magnitude as that obtained by the removal of corpora lutea, but leaves the other ovarian functions intact. Replacement therapy with oestrogen is required for the stimulation of $\alpha$-lactalbumin activity to be similar to that in the intact animal (Bussmann et al., 1983), whereas progesterone replacement treatment effectively suppresses milk synthesis induced by ovariectomy (Kuhn, 1969).

In agreement with the findings of Edery et al. (1985) working on the mouse mammary gland at different reproductive stages, we found that in rats, ovariectomy and the onset of lactogenesis decreases the concentration of EGF receptors to values similar to those seen during established lactation.

Replacement treatment with ovarian steroids showed that progesterone does not prevent the fall in EGF receptor concentrations seen after ovariectomy. Treatment with oestradiol and progesterone together does not unblock the action of the latter but restores EGF receptor values to those of the intact animal. This finding confirms previous studies in nondifferentiated mouse mammary glands (Vonderhaar, 1987) indicating that the stimulatory action of progesterone and oestrogen together is due to the regulation of the concentration of the EGF receptor (Haslam et al., 1992).
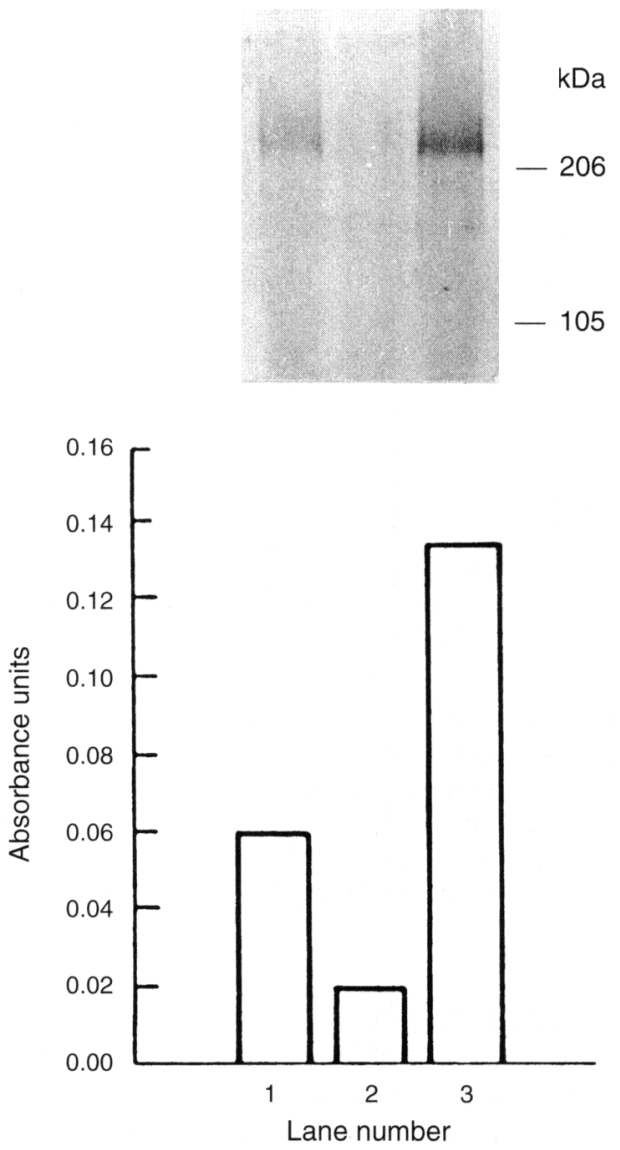

Fig. 6. Representative fluorography of cross-linked ${ }^{125}$ I-labelled insulin-like growth factor II (IGF-II) bound to mammary acini membranes from rats at day 19 of pregnancy preincubated in the absence (lane 1) or in the presence of $3 \times 10^{-7} \mathrm{~mol} \mathrm{IGF-II} \mathrm{1^{-1 }}$ (lane 2) or $5 \mathrm{mmol}$ mannose 6-phosphate $\mathrm{1}^{-1}$ (lane 3). Positions of the molecular mass markers are indicated on the right. Bars under the lanes represent the absorbance of the cross-linked receptor quantified by densitometry.

In the uterus, oestradiol upregulates the EGF receptor in immature rats (Makku and Stancel, 1985) and in ovariectomized adult mice (Das et al., 1994). Oestradiol, given in combination with progesterone, produces an increase in mRNA encoding the EGF receptor, which is not concomitant with the increase in receptor concentration in the mouse uterus (Das et al, 1994). In the human cell line T-47D, both the EGF receptor and its mRNA are upregulated by progestagens (Murphy et al., 1986, 1988). The differences in responses may be due to tissue- or physiological stage-specific conditions.

Treatment of ovariectomized pregnant rats with oestradiol produces a further decrease in EGF receptors together with the appearance in the acid-alcohol extract of an EGF-like molecule. Western blot analysis of the acid-alcohol extract with a rabbit polyclonal antibody against TGF $\alpha$, did not reveal any specific band for TGF $\alpha$. However, the EGF-like molecule, the concentration of which was increased by oestradiol treatment, was found to bind to heparin-Sepharose and eluted with $0.75 \mathrm{~mol} \mathrm{NaCl} \mathrm{l}^{-1}$ (L. Bussmann and E. Charreau, unpublished observations). These results indicate a paracrine control of the mammary growth by an EGF-like growth factor which has an 


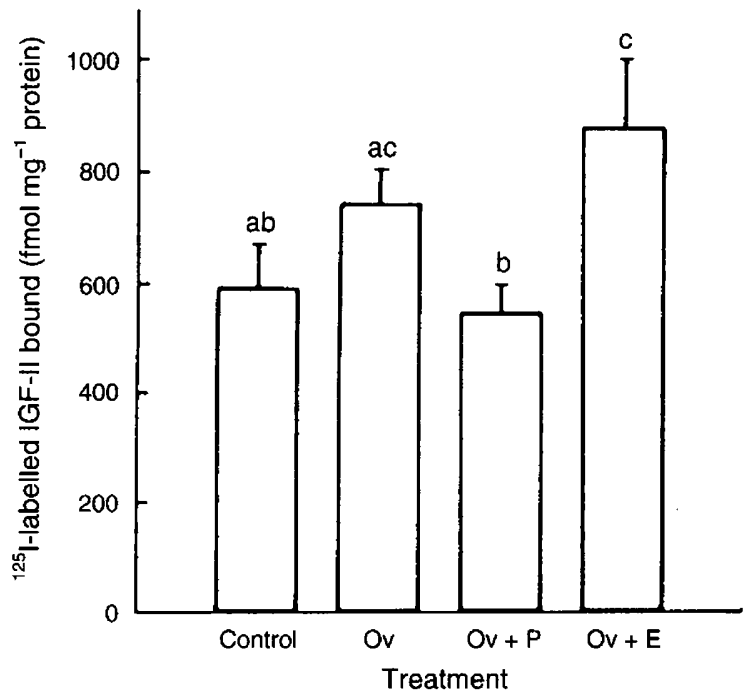

Fig. 7. Effect of steroid replacement to ovariectomized rats on the concentration of the insulin-like growth factor II (IGF-II) receptor. Membranes from mammary gland acini of control, ovariectomized $(\mathrm{Ov})$, and ovariectomized treated with progesterone $(\mathrm{Ov}+\mathrm{P})$ or oestradiol $(\mathrm{Ov}+\mathrm{E})$ were incubated. Values are means \pm SEM; $n=5$ rats per group. Bars with the same letter(s) are not significantly different at $P<0.05$.

affinity for heparin that lies between platelet-derived growth factor (PDGF) and those of heparin-binding EGF (Higashiyama et al., 1992). In the mouse mammary gland, an EGF-like growth factor activity, MDGF, has been described by Vonderhaar (1984), and the presence of amphiregulin, which binds to the EGF receptor and heparin, was recently reported by Kenney et al. (1995).

The presence of high-affinity binding sites for IGF-I has been reported in rat mammary glands and their concentrations were higher in rats at day 7 of pregnancy compared with virgin or lactating rats (Collier et al., 1989). Ovariectomy, which initiates milk secretion and is responsible for the change in the mammary gland from a growing stage to a secretory one, induces down-regulation of the receptors for IGF-I and EGF. A similar fall in concentrations of the IGF-I receptor has been described in sheep at parturition and lactation (Winder et al., 1993). In contrast, lactogenesis in cows is accompanied by an increase in IGF binding and the appearance of a $127 \mathrm{kDa}$ IGF-I subunit, in addition to the $134 \mathrm{kDa}$ subunit (Dehoff $e$ al., 1988; Hadsell et al., 1990).

Colostrum and milk are major sources of growth-promoting factors (Corps and Brown, 1987), and immunohistochemical studies have shown that in rat mammary glands IGF-I is present only in myoepithelial cells (Marcotty et al., 1994). Downregulation of the IGF-I receptor during lactogenesis could indicate the uptake and transfer of the growth factor from the myoepithelial cells or serum to milk, as described in goats (Prosser et al., 1991).

The IGF-I and EGF receptor content in mammary glands of ovariectomized rats showed a different pattern after replacement treatment with ovarian steroid hormones. Oestrogen was shown to regulate the IGF-I receptor, since ovariectomy produced a decrease in the binding sites and administration of oestradiol partly restored the sites, even when injected together with progesterone. This would allow IGF-I to exert its mitogenic effect during pregnancy, when progesterone concentrations are high and preclude a lactogenic type II action by IGF-I. In humans, using an oestrogen-responsive cell line, oestradiol was found to act in a similar manner (Steward et al., 1990). When incubated in the absence of oestrogen, these cells showed a six-fold decrease in IGF-I binding sites, with a similar effect observed on mRNA encoding the IGF-I receptor. This finding suggests that oestradiol exerts its action at the transcriptional level. The decrease in receptors after ovariectomy observed in the work reported here was not of the same magnitude as that observed by Steward et al. (1990), possibly due to the shorter time of hormone deprivation before the experiment and to the action of some residual oestradiol.

Affinity cross-linking of ${ }^{125}$ I-labelled IGF-II showed only one band corresponding to the type II receptor. No radioactivity was observed associated with either the type I receptor or with IGF-binding proteins such as IGFBP3, as described in cultured mammary cells from mice (Hadsell et al., 1994). Recently, the IGF-Il receptor was confirmed as being identical to the mannose 6-phosphate receptor (MacDonald et al., 1988) which targets acid hydrolases to lysosomes (Pfeffer, 1988). The results of the covalent cross-linking of ${ }^{125}$ I-labelled IGF-II to the receptor when incubated in the presence of mannose-6phosphate presented here support the hypothesis that both receptors are identical. In agreement with Collier et al. (1989) we showed that, after differentiation of the mammary gland to a secretory state, the concentration of the IGF type II receptor changed slightly. When covalent cross-linking was carried out, an increase in labelling of more than $50 \%$ was found in membranes from ovariectomized rats. Oestradiol treatment, which increases lactose synthesis (Bussmann et al., 1983), significantly increased concentrations of the IGF-II/mannose-6phosphate receptor. This may reflect the shift from growth and development of the gland to a secretory role, and hence to an increase in lysosomal movement.

Our results suggest that, while the crucial role of EGF and IGF-I in the growth and differentiation of the mammary gland might be mediated by changes in receptor concentration accompanying lactogenesis II, the progesterone block of this physiological event is not mediated by these growth factors.

The authors thank J. C. Calvo and A. Colman Lerner for critical reading of the manuscript. This work was supported by grants from the CONICET and BID-CONICET II programs.

\section{References}

Bussmann L and Deis RP (1979) Studies concerning the hormonal induction of lactogenesis by prostaglandin $\mathrm{F}_{2 a}$ in pregnant rats Journai of Steroid Biochemistry 11 1485-1489

Bussmann L, Konynckx A and Deis RP (1983) Effect of estrogen and placental lactogen on lactogenesis in pregnant rats Biology of Reproduction 29 535-54 I

Carpenter G and Cohen S (1979) Epidermal growth factor Annual Review of Biochemistry 48 193-216

Collier RJ, Ganguli S, Menke PT, Buonomo FC, McGrath MF, Kotts CE and Krivi GG (1989) Changes in insulin and somatomedin receptors and uptake of insulin, IGF-I and IGF-II during mammary growth, lactogenesis and lactation. In Biotechnology in Growth Regulation pp 153-163 Eds RB Heap. CG Prosser and GE Lamming. Butterworth, London 
Corps AN and Brown KD (1987) Stimulation of intestinal epithelial cell proliferation in culture by growth factors in human and ruminant mammary secretions Joumal of Endocrinology 113 285-290

Das SK, Tsukamura H, Paria BC, Andrews GK and Dey SK (1994) Differential expression of epidermal growth factor receptor (EGF-R) gene and regulation of EGF-R bioactivity by progesterone and oestradiol in the adult mouse uterus Endocrinology 134 97I-981

Davis SR, Gluckman PD, Hart IC and Henderson HV (1987) Effects of injecting growth hormone or thyroxine on milk production and blood plasma concentrations of insulin-like growth factors I and II in dairy cows Journal of Endocrinology 114 17-24

Dehoff MH, Elgin RG, Collier RJ and Clemmons DR (1988) Both type I and II insulin growth factor receptor binding increase during lactogenesis in bovine mammary tissue Endocrinology 122 2412-2417

Dembinski TC and Shiu PC (1987) Growth factors in mammary gland development and function. In The Mammary Gland Development, Regulation and Function pp 355-38I Eds MC Neville and CW Daniel. Plenum, New York

Edery M, Pang K, Larson L, Colosi T and Nandi S (1985) Epidermal growth factor receptor levels in mammary glands in various physiological states Endocrinology 117 405-411

Elizalde P, Lanari C, Kordon E, Tezon J and Charreau EH (1990a) Transforming growth factor- $\beta$ activities in lines of hormone-dependent and independent mammary adenocarcinomas induced by medroxyprogesterone acetate in BALB/c mice Breast Cancer Research and Treatment 16 29-39

Elizalde P, Lanari C, Bussmann L, Kordon E, Guerra F, Savin M and Charreau EH (1990b) Insulin-like growth factor-I production and receptors in mammary adenocarcinomas induced by medroxyprogesterone acetate in BALB/c mice Journal of Experimental and Clinical Cancer Research 9 193-203

Fleet IR, Goode JA, Hamon MH, Laurie MS, Linzell JL and Peaker M (1975) Secretory activity of goat mammary glands during pregnancy and the onset of lactation Journal of Physiology 251 763-773

Flint DJ, Tonner E, Beattie J and Gardner M (1994) Several insulin growth factor-I analogues and complexes of insulin-like growth factor-I and -ll with insulin-like growth factor-binding protein-3 fail to mimic the effect of growth hormone upon lactation in the rat Joumal of Endocrinology 140 $211-216$

Hadsell DL, Campbell PG and Baumrucker CR (1990) Characterization of the change in type I and II insulin-like growth factor receptors of bovine mammary tissue during the pre- and postpartum periods Endocrinology 126 $637-643$

Hadsell DL, Gibson CA and Baumrucker CR (1994) Insulin-like growth factor (IGF) binding to a murine mammary epithelial cell line Journal of Cell Physiology $161435-440$

Haslam SZ, Counterman LJ and Nummy KA (1992) EGF receptor regulation in normal mouse mammary gland Journal of Cell Physiology 152 553-557

Higashiyama S, Lau K, Besner GE, Abraham JA and Klagsbrun M (1992) Structure of heparin-binding EGF-like growth factor Joumal of Biological Chemistry 267 6205-6212

Imagawa W, Spencer EM, Larson L and Nandi S (1986) Somatomedin-C substitutes for insulin for the growth of mammary epithelial cells from normal virgin mice in serum-free collagen gel culture Endocrinology 119 2695-2699

Kasuga M, Van Obberghen E, Nissley SP and Rechler MM (1981) Demonstration of two subtypes of insulin-growth factor receptors by affinity crosslinking Journal of Biological Chemistry 256 5305-5308

Kenney NJ, Huang RP, Johnson GR, Wu JX, Okamura D, Matheny W, Kordon E, Gullick WJ, Plowman G, Smith GH, Salomon DS and Adamson ED (1995) Detection and location of amphiregulin and cripto-1 expression in the developing postnatal mouse mammary gland Molecular Reproduction and Development $41277-286$

Kuhn NJ (1969) Progesterone withdrawal as the lactogenic trigger in the rat Journal of Endocrinology 44 39-54

Liu TM and Davis JW (1967) Induction of lactation by ovariectomy in pregnant rats Endocrinology 80 1043-1050

Lowry OH, Rosebrough NJ, Farr AL and Randall RJ (1951) Protein measurement with the Folin phenol reagent Journal of Biological Chemistry 193 265-276

MacDonald RG, Pfeffer SR, Coussens L, Tepper MA, Brocklebank CM, Mole JE, Anderson JK, Chen E, Czech MP and Ulrich A (1988) A single receptor binds both insulin-like growth factor II and mannose 6-phosphate Science 239 1134-1137
Makku VR and Stancel GL (1985) Regulation of epidermal growth factors receptors by oestrogen Journal of Biological Chemistry 260 9820-9824

Marcotty Ch, Frankenne F, Meuris S and Hennen G (1994) Immunolocalization and expression of insulin-like growth factor I (IGF-l) in the mammary gland during rat gestation and lactation Molecular and Cellular Endocrinology $\mathbf{9 9}$ 237-243

Molinolo AA, Lanari C, Charreau EH, Sanjuan N and Dosne Pasqualini C (1987) Mouse mammary tumours induced by medroxyprogesterone acetate: immunohistochemistry and hormonal receptors Journal of National Cancer Institute 79 1341-1350

Munson PJ and Rodbard D (1980) Ligand: A versatile computerized approach for characterization of ligand-binding systems Analytical Biochemistry 107 230-239

Murphy LC, Murphy LJ and Shiu RPC (1988) Progestin regulation of EGF-receptor mRNA accumulation in T-47D human breast cancer cells Biochemical and Biophysical Research Communications 150 192-196

Murphy LJ, Sutherland RL, Stead B, Murphy LC and Lazarus L (1986) Progestin regulation of epidermal growth factor receptor in human mammary carcinoma cells Cancer Research 46 728-734

Myal Y, Shiu RPC, Bhanmick B and Bala M (1984) Receptor binding and growth-promoting activity of insulin-like growth factors in human breast cancer cells (T47D) in culture Cancer Research 44 5486-5490

Papadimitriou JT, Shearer M and Stocker MGP (1977) Growth requirements of human mammary epithelial cells in culture International journal of Cancer 20 903-910

Pfeffer SR (1988) Mannose 6-phosphate receptors and their role in targeting proteins to lysosomes Journal of Membrane Biology 103 7-16

Prosser CG, Fleet IR, Davis AJ and Heap RB (1991) Mechanism of secretion of plasma insulin-like growth factor-I into milk of lactating goats journal of Endocrinology 131 459-466

Roberts AB, Lamb LC, Newton DL, Sporn MB, DeLarco JE and Todaro GJ (1980) Transforming growth factors: isolation of polypeptides from virally and chemically transformed cells by acid/ethanol extraction Proceedings of the National Academy of Sciences USA 77 3494-3498

Sankaran L and Topper YJ (1987) Is EGF a physiological inhibitor of mouse mammary casein synthesis? Unphysiological responses to pharmacological levels of hormones Biochemical and Biophysical Research Communications 146 121-125

Scatchard G (1949) The attractions of proteins for small molecules and ions New York Academy of Sciences 51 660-672

Shyamala G and McBlain WA (1979) Distinction between progestin- and glucocorticoid-binding sites in mammary glands Biochemical Journal 178 $345-352$

Stein P, Bussmann L and Tessone $M$ (1995) In vivo regulation of the steroidogenic activity of rat luteal cells by insulin Journal of Steroid Biochemistry and Molecular Biology 52 329-335

Steward AJ, Johnson MD, May FEB and Westley BR (1990) Role of insulin-like growth factors and the type I insulin-like growth factor receptor in the oestrogen-stimulated proliferation of human breast cancer cells Journal of Biological Chemistry $26521 \quad 172-21178$

Taketani Y and Oka T (1983) Epidermal growth factor stimulates cell proliferation and inhibits functional differentiation of mouse mammary epithelial cells in culture Endocrinology 113 871-877

Threadgold LC, Coore HG and Kuhn NJ (1982) Monosaccharide transport into lactating rat mammary acini Biochemical Journal 204 491-501

Topper YJ and Freeman CS (1980) Multiple hormone interaction in the developmental biology of the mammary gland Physiological Review 60 1049-1106

Turkington RW (1969) The role of epidermal growth factor in mammary gland development in vitro Experimental Cell Research 57 79-85

Vonderhaar BK (1984) Hormone and growth factors in mammary gland development. In Control of Cell Growth and Proliferation PP 11-33 Ed. CM Veneziale. Van Nostrand-Reinhold, Princeton, NJ

Vonderhaar BK (1987) Local effects of EGF, TGFa, and EGF-like growth factors on lobuloalveolar development of the mouse mammary gland in vivo journal of Cell Physiology 132 581-584

Winder SJ, Wheatley SD and Forsyth IA (1993) Receptor binding of insulin-like growth factor-I to mammary microsomes from non-pregnant, pregnant and lactating sheep Journal of Endocrinology 136 297-304 